\title{
China's 'Steel Hunger': A Comparative Analysis of SOE and NSOE Internationalization Motivations and Attitudes towards Risk
}

\author{
Monica Ren \\ Macquarie University \\ E-Mail: Monica.Ren@mq.edu.au \\ Robert Jack \\ Macquarie University \\ E-Mail: rob.jack@mq.edu.au
}

\begin{abstract}
In this paper, we present two exploratory case studies' detailing the internationalisation of a Chinese mining, state-owned enterprise (SOE) and a nonstate-owned enterprise (NSOE). Increasing outward foreign direct investment (OFDI) from China's extractive industries, particularly its steel sector, is now one of the more dramatic aspects of globalisation in the new millennium. It has led to an increased interest in what motivates these firms and how their internationalisation may be shaped by the risks inherent in their pursuit of international expansion. In the study 13 face-to-face interviews are conducted with both senior and functional level managers across both firm types. This data analysis reveals that institutional factors and significant international experience influences SOEs to be 'risk tolerating' while influencing NSOEs to be 'risk averse'. This paper offers a set of propositions that highlight how motivations and risk attitudes are shaped by firm ownership and institutional factors, which ultimately influence the location choice for each firm.
\end{abstract}

Keywords: State-Owned Enterprises (SOEs), Non-State-Owned Enterprises (NSOEs), Steel, China, Internationalization Motivations, Motivations, Risk 


\section{INTRODUCTION}

Many large Chinese mining State Owned Enterprises (SOEs) and Non-State Owned Enterprises (NSOE) are driven to invest abroad by their need to secure access to natural resources (such as oil, gas and mineral deposits) (KPMG \& SCSC, 2012; UNCTAD, 2007). Although a natural resource world leader in terms of both reserves and the production of several metals and minerals, China's per capita reserves are far below the global average (Liu, 2011; M2PressWire, 2009). This scarcity results in the decision by Chinese mining companies to actively buy up mining assets internationally. In fact, the portion of outward foreign direct investment (OFDI) from China's mining sector is the largest or second largest investment when compared to all other sector investments (MOFCOM, et al., 2006, 2007, 2008, 2009, 2010, 2011, 2012).

As a measure of a nation's enhanced economic progress and increasing development, the steel industry is often viewed as a key strategic sector (Nolan \& Yeung, 2001; World Steel Association, 2012). The gradual opening of China's markets to foreign trade and investment has led to the rapid growth of its steel sector Chinese steel production increased at an average annual rate of $7 \%$ during the $1980 \mathrm{~s}$, $10 \%$ during the 1990 s, and by nearly $20 \%$ in the 2000 s. With further increases to 683.9 million tons in 2011, China (followed by Japan and the United States) today continues to be the world's leading steel-producer (World Steel Association, 2012).

China's steel industry is characterised by a decentralized structure with many of its larger steel producers classified as state-owned enterprises (SOEs) and a significant proportion of smaller producers classified as non-state-owned enterprises (NSOEs) (Holloway, et al., 2010). As with other major sectors of the Chinese economy, NSOEs have been active in overseas investment (Jiang, 2009); and in 2011 they accounted for approximately $44 \%$ of the total OFDI flow (Askci, 2012).

In view of the potential impact of the NSOE contribution to this sector and their significant growth, we compare the internationalisation characteristics of NSOEs with that of SOEs and investigate how these characteristics contribute to Chinese OFDI. By drawing on distinctions between SOEs and NSOEs, we also seek to contribute the emerging literature on Chinese firm level OFDI. The paper is structured as follows we review the literature related to OFDI motivations, risks, institutional theory, and location choices. We then discuss our chosen methodology and present an analysis of the results obtained. After discussing these results we offer six propositions that can form the basis of future research directions. Our paper then offers a conclusion and an overview of its managerial implications and limitations of the current research. 


\section{BACKGROUND AND REVIEW OF THE LITERATURE}

\section{Motivations of Chinese Mining OFDI}

The theories of foreign direct investment have long recognized that firms invest overseas with different motives (Behrman, 1969). Moreover, these motives may change. Dunning and Lundan (2008) note that many larger MNEs (post 2000) pursue multiple objectives and consequently engage in FDI that combines the goals of two or more motivations. As MNEs become more established and experienced, each type of MNE activity may become aggressive - in the sense that the investing company seeks to take proactive action to advance its own strategic objectives - or become defensive in the sense that its behaviour is a reaction to actions taken by its competitors or foreign governments, which then require the company to protect its market position (Dunning \& Lundan, 2008).

In the literature, four kinds of motivations for FDI (largely evolving from Dunning's research - $(1977,1998 ; 1993)$ ) are generally accepted (Buckley, et al., 2007; Cai, 1999; Deng, 2003, 2004; Kang \& Jiang, 2012): resource seeking; foreign market seeking; efficiency seeking; and strategic asset seeking. Further fesearch has attempted to apply these motivations to the internationalisation of Chinese MNEs (Buckley, et al., 2007; Deng, 2003, 2004; Voss, et al., 2008), although the mining/steel sector in China has only received limited attention. Resource-seeking motives in extractive industries are represented by their global search for cheap natural resources (Kraemer \& Tulder, 2009). Lu (2003) highlights the fact that such resource-based motivation can be multi-dimensional and emphasises the specific variations undertaken by Chinese mining firms, namely, seeking scarce resources for the domestic market; maintaining the stability of their raw materials' source; and using location advantage in terms of resource production. Due to a scarcity of the natural resources needed to support China's rapid industrialisation, the primary incentive of Chinese mining firms may be to undertake FDI.

China's accession to the World Trade Organisation (WTO), and its adoption of the 'go global strategy' has accelerated the global reach of Chinese MNEs (Voss, et al., 2008). The business environment of Chinese enterprises has dramatically changed (Deng, 2007), as growing domestic competition is now likely to 'force' many Chinese companies, especially NSOEs that lack institutional support, to seek new markets abroad. This is likely to provide a fresh stimulus for Chinese OFDI flows (Taylor, 2002; Voss, et al., 2008).

Efficiency-seeking FDI benefits the economies of scale and scope and risk diversification of firms (Dunning \& Lundan, 2008). It occurs when outward 
investment seeks lower-cost locations for its operations (Dunning, 2000), in particular the search for lower-cost labour (Buckley, et al., 2007). Due to (comparatively) low domestic labour costs and inexpensive land in China, this efficiency-based determinant is less likely to apply to firms' operating in the mining sector (Buckley, 2008; Deng, 2003). Its impact on OFDI is also chiefly associated with the internationalization of labour intensive industries across both the manufacturing and service sectors, and thus its relevance for the more capital intensive mining sector becomes less certain (First Finance Daily, 2010; Qing, 2010).

Strategic asset-seeking FDI is driven by a firm's need to access complementary resources, notably various kinds of knowledge, so as to upgrade its own capabilities (Deng, 2007). A number of investments taken on by Chinese mining firms are driven by the search for strategic assets, including superior mining skills, marketing expertise, external markets, exploration, and mining technology (Huang, 2008). This mining technology is relevant to both the extraction and prospecting of mines $(\mathrm{Lu}$, 2003). The motives may be especially important for newly emerging companies in developing economies that are eager to develop their competitive assets rapidly (UNCTAD, 2007). This trend is highlighted by Kumar and Chadha's (2009) research on India's OFDI from its steel industry, where the dominant motivation of senior managers there is to evolve their companies into global enterprises by acquiring access to strategic resources, such as industry recognised brand names and product networks.

\section{Institutional Influence on Motivations}

Another consistent theme across the recent literature on China's OFDI is the view that Chinese MNEs are motivated not only by traditional determinants, but also by political considerations (Alon, et al., 2009; Buckley, 2008; Buckley, et al., 2007; Deng, 2007; He \& Lyles, 2008; Luo, et al., 2010; Morck, et al., 2008; Naidu \& Mbazima, 2008; Wang, 2009). Since the 1980s, the Chinese government has required overseas subsidiaries to achieve one of four goals - introduction of advanced technology; access to raw materials; foreign exchange earnings, and expansion of exports (Deng, 2003).

The extant literature implies that institutional support may shape the motivations of both types of Chinese mining firms. This institutional-based view asserts that the strategies behind a MNE's OFDI decisions are affected by 'the rules of the game' namely, the host country's institutions (Dunning \& Lundan, 2008; Peng, et al., 2009; Peng, et al., 2008). It is also argued that institutional theory is the most useful approach when studying business strategy in emerging economies (Wright, et al., 
2005). The theory can also assist in explaining the distinctiveness found in the behavior of outward investing by Chinese mining firms (Buckley, et al., 2007), since the home institutional environment is both formally and informally enforced by the government and its agents (Scott, 2002), the policies of which then affect the norms and cognitions that influence investment, including OFDI behaviour (Buckley, et al., 2007).

Institutional context theory is 'motivated by considerations of not just exploitation but also enhancement or development of capabilities' (Madhok, 1997: 41), which suggests that the institutional context includes both tangible (resources) and intangible assets (capabilities) of a firm (Brouthers \& Brouthers, 2000; Madhok, 1997). Using this as a basis for further development, we present in Table 1 below an overview of the tangible and intangible assets owned by Chinese mining firms.

\section{Location Choices and The Risk Attitudes of Steel Firms}

Although risk is present in various forms and levels of firm internationalisation, it becomes more evident in large scale investments (Rockett, 1999). Large-scale investments are required in the mining sector, and they can result in significant budget overruns, delivery delays, failures, financial losses, environmental damage, and even injuries and loss of life (Beer \& Ziolkowski, 1995). In addition, international operations are highly uncertain (Ayyub, et al., 2010). Incomplete information about host countries, limited control over the activities of foreign managers, political insecurities, the risk of fluctuations in exchange rates (Bausch \& Krist, 2007) and a lack of international experience (Agarwal \& Ramaswami, 1992; Brouthers, et al., 1996; Kim \& Hwang, 1992; Luo \& Peng, 1999) all can impact the level of risk. Therefore, steel firm internationalization is a relatively high-risk action and an important issue to be considered precisely by those firms that are undertaking FDI.

Location is a key consideration for foreign direct investment (Buckley \& Casson, 1976; Dunning, 1998; Nachum, 2000; Pak \& Park, 2005; Porter, 1998; Ramasamy, et al., 2012; Root, 1994). Location choices have also gained additional strategic importance as sources of new learning, knowledge creation, and new or enhanced competitiveness (Dunning, 1998, 2001, 2009; Pak \& Park, 2005). UNCTAD (2007) emphasises that mining MNEs will list criteria, such as government policies and regultory systems, as among the most important determinants of any location advantage. As a result, host governments can either empower or inhibit MNEs with their actions and that uncertainty is reflected in country- based risks. 


\section{Table 1 Institutional Influences on Chinese Steel SOE and NSOE's Internationalization}

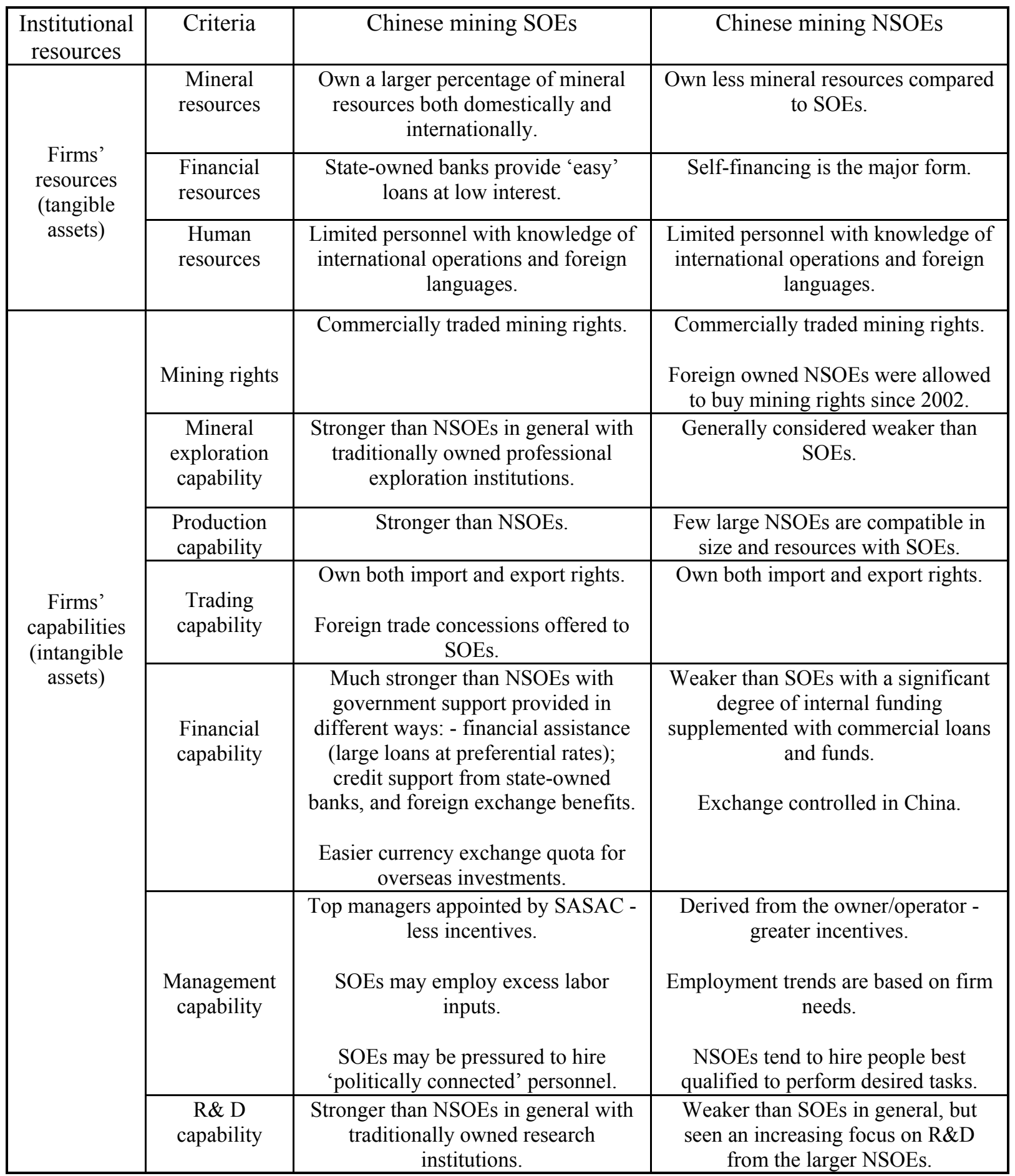

Researchers have increasingly drawn attention to the significant presence of Chinese mining firms in Africa that have interests in Sudan, Angola, Nigeria, Niger, and the Congo (Alden \& Davies, 2006; Chuan \& Orr, 2009; Ericsson, 2010; Gu, 2009; Haglund, 2008; Naidu \& Davies, 2006; Naidu \& Mbazima, 2008; Shen, 2013; 
Tull, 2006; Zafar, 2007). Figure 1 illustrates the main foreign investment destinations for Chinese mining firms since 2005.

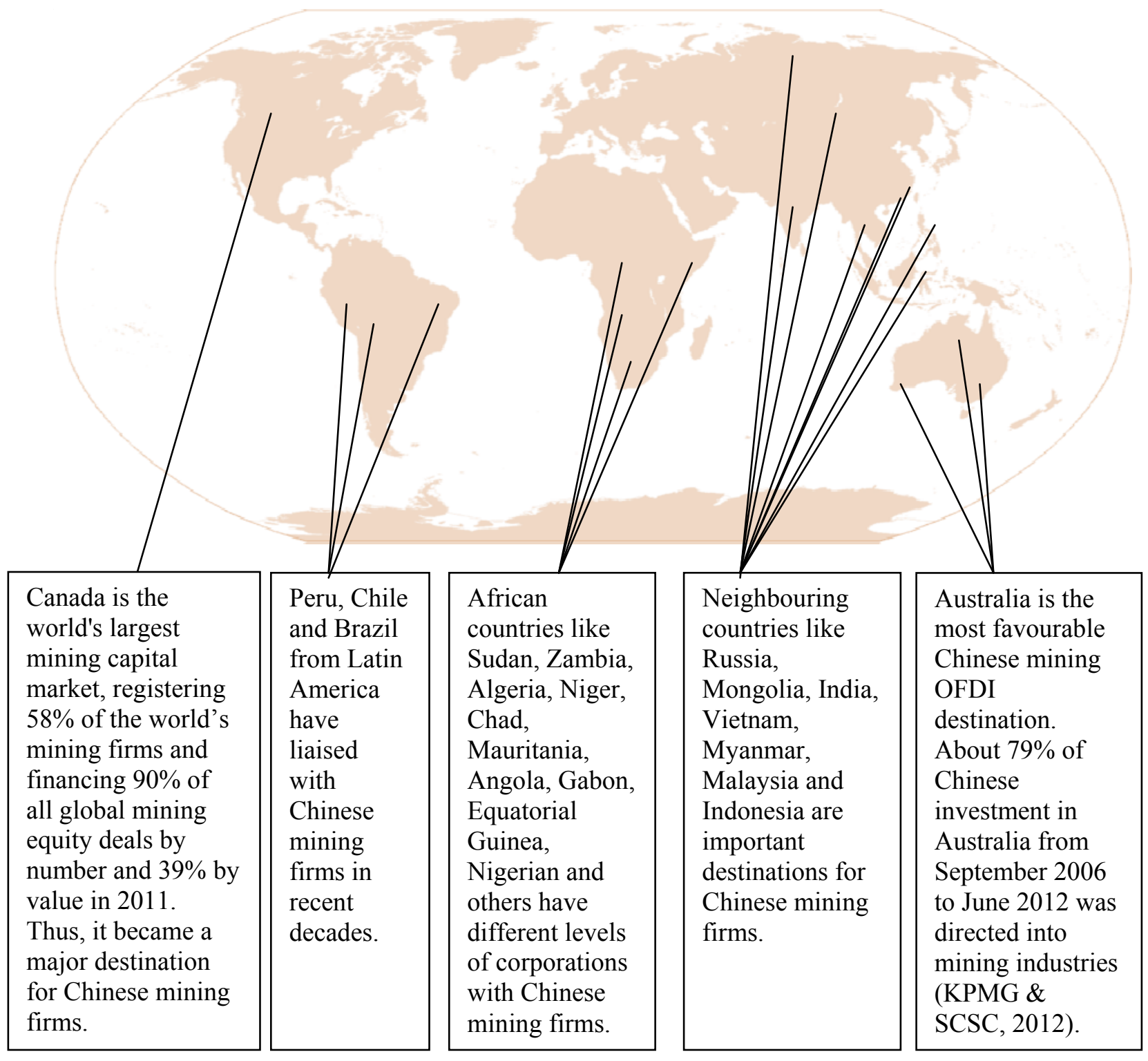

Sources: Data extracted from Corkin (2007); Davies et al. (2008); Naidu and Davis (2006); NBD China (2009); Reuters (2010); Sun (2007); Wang and Jiang (2007); KPMG and SCSC (2012);

$$
\text { CCC(2013). }
$$

Figure 1 Main OFDI destinations for Chinese mining firms (2013)

With the exception of Canada and Australia, many of these are perceived as 'high risk' locations. Chinese OFDI in these locations is primarily undertaken by SOEs and is tied to China's political economy (Luo, et al., 2010). The Chinese government has shown strong support for these firms in international relations and in the specific 
policies and financial loans underpinning their internationalization in these markets (Kolstad \& Wiig, 2012). Indeed, Naidu and Davies (2006) explain that China's need for essential raw materials results in its government being prepared to shoulder most of the risk for Chinese SOEs that are investing in Africa. This policy implies that firmlevel risks can be dissolved at the home country level, particularly for the SOEs and underscores Buckley et al. (2007) and Buckley's (2008) comment that the Chinese mining industry FDI is prepared to invest in what are commonly regarded as 'high risk' geographic environments in order to secure valuable raw material deposits.

\section{Location Choices and Multinational Experience}

Researchers have asserted that multinational experience can help a firm promote internationalization (Agarwal \& Ramaswami, 1992; Brouthers, et al., 1996; Contractor \& Lorange, 1988; Kim \& Hwang, 1992; Luo \& Peng, 1999), and may even have a positive impact on its internationalization process. This point is important, as the accumulation of international experience is seen as one of the advantages that mining SOEs do enjoy, derived from the unique institutional environment they experience. As many of these SOEs were previously government institutions, before being transformed into enterprises (Rosen \& Hanemann, 2009), support and patronage are provided to them by the government (Gao, et al., 2010). A strategic consequence of this ongoing government support is that 'inexperienced firms' (i.e., NSOEs who have less accumulated international experience) tend to exhibit a greater preference for geographically close and similar markets than do those firms with broader, more diverse international operating experience (Rosen \& Hanemann, 2009).

It remains unclear, however, how Chinese mining firms, with distinct ownership types, behave in terms of their risk attitudes and how those attitudes toward risk and their accumulated international experiences impact their location choices.

\section{METHODOLOGY}

\section{Research Design and Data Collection}

Our paper undertakes an exploratory comparative case study of a Chinese steel SOE and NSOE. The characteristics of case study research make it a most suitable methodology for the topic (Yin, 2009). The comparison of similarities and differences across cases allows the researchers to suggest explanations for possible patterns, trends, or linkages found. Eisenhardt (1989) argues that theory building from case studies can be enhanced by choosing cases that highlight extreme situations or polar types in which the singular under investigation is observable. In the light of this 
development, this empirical study was designed to explore any possible differences and similarities in the dynamics of change between two diverse entities.

According to Dubois and Gadde (2002), sample size in case research is relative and depends on the purpose of the study. The number of cases should not be characterised and viewed as 'the more, the better' (Fletcher \& Plakoyiannaki, 2011). In March 2010, with assistance from the China Mining Association (CMA) and the China Steel Association (CISA)'s, a short list of four firms from the Chinese steel industry was finalised. Of these four firms, one steel SOE and one steel NSOE committed to participate in the research. These firms were significant in both the size of their productive capacity (ranked within the top 10 worldwide in 2012) and the scope of their international operations

Face-to-face interviews were undertaken in China between July 2010 and September 2011, and 13 interviews, each lasting between 60 and 120 minutes, were conducted with both senior and functional managers' directly involved in each firm's international operations. Sensitive data about Chinese business policies and strategies are best obtained through such face-to-face interviews (Ahlstrom \& Bruton, 2008). Open-ended questions were also utilised and focused on institutional factors, motivations, risk attitudes, location choices, and other relevant issues directly related to each firm's internationalisation. Table 2 below details the key information about the respondents

All interview transcriptions were prepared and typed in Chinese Mandarin by the primary researcher to enable the researchers to immerse themselves in the data, an important experience to identify emerging insights (Patton, 2002). Once this process was completed, the transcript was proofread and emailed as an attachment to each interviewee with a request for the interviewee to check the document for accuracy of the interview. Any suggested changes were incorporated and further cross checks were made for full accuracy. This type of 'member check' increases the validity and reliability of data by avoiding possible interpretation errors (Flick, 2008).

Qualitative data analysis was conducted manually to organise and structure the interview transcripts and aid in the coding efforts. Then, the clustering of the data involved was undertaken to identify associations therein (Miles \& Huberman, 1994). Once the data was clustered, the findings for each context were summarised in conceptually clustered matrices. This matrix technique promotes pattern matching and a more effective categorisation of data (Miles \& Huberman, 1994). The emergent findings are then tied to the extant literature, thereby enhancing internal validity and generalizability (Eisenhardt, 1989). These analysed results were then translated into 
English to avoid losing any important information with a translation of the whole transcript.

Table 2 Primary Data Collection Details

\begin{tabular}{lcccc}
\hline & Position of the interviewee & Date & $\begin{array}{c}\text { Length } \\
\text { (mins) }\end{array}$ & Protocol used \\
\hline 1 & NSOE - Steel & $7 / 07 / 2010$ & 60 & Senior Management \\
\hline 2 & Board Member & $7 / 07 / 2010$ & 60 & Senior Management \\
\hline 3 & Financial Advisor of Board & $15 / 07 / 2010$ & 90 & Senior Management \\
\hline 4 & Vice Principal & $16 / 07 / 2010$ & 90 & Senior Management \\
\hline 5 & Chief Financial Officer (CFO) & $16 / 07 / 2010$ & 60 & Senior Management \\
\hline 6 & General Manager & $16 / 07 / 2010$ & 90 & Senior Management \\
\hline 7 & Head of Australian subsidiary & $15 / 07 / 2010$ & 60 & Functional Management \\
\hline \multicolumn{1}{c}{ Manager of raw materials/resources } & & & \\
\hline 2 & Supplies Department & $14 / 04 / 2011$ & 120 & Senior Management \\
\hline 3 & SOE - Steel & $15 / 04 / 2011$ & 90 & Senior Management \\
\hline 4 & Hong Kong Subsidiary investment manager & $12 / 07 / 2011$ & 60 & Functional Management \\
\hline 5 & Hong Kong Subsidiary CEO & $13 / 07 / 2011$ & 90 & Senior Management \\
\hline 6 & Head of Administrative Officer & $13 / 09 / 2011$ & 60 & Functional Management \\
\hline
\end{tabular}

To enhance 'data triangulation' (Guion, et al., 2011) we supplemented the interview data with secondary data that included background information from public sources, such as newspapers, company archives, observation, field notes, research journals, Internet resources, and press releases. Triangulation ensures the validity of the processes and, in case studies this can be achieved by using multiple data sources (Yin, 2009) This secondary data incorporated information gathered from the following sources - websites of the case-study firms; annual reports; press releases; company newsletters; personal blogs, and internal publishing archives. Such information was used as evidence to confirm details from different respondents. For instance, if the public data (e.g., years, quantities) did not match the information given 
by the respondents, the researcher then used cross-references from secondary data to correct any misinformation. This was important as sufficient information was needed to characterize and explain the unique features of the cases, as well as to highlight common characteristics from the comparisons of the cases (Ghauri, 2004).

\section{FINDINGS AND DISCUSSION}

Table 3 summarises the findings of the research study by displaying the motivations of each case firm, their risk attitudes, their first international experience, and their location choices in terms of different kinds of business (e.g. for obtaining resources or exporting business).

\section{Motivations}

Our interview data reveals that resource-seeking is indeed a common primary motive for both categories steel firms; however, the initial incentives that trigger this motivation are distinct to each type. Consistent with other studies that have focused on SOEs, political strategic considerations were seen to be an important motivation (Buckley, 2008; Buckley, et al., 2007; Deng, 2007; He \& Lyles, 2008; Luo, et al., 2009; Morck, et al., 2008; Naidu \& Mbazima, 2008; Wang, 2009) in this study. However, the new findings also reveal that the extent to which this motivation is a dominant consideration is debatable. SOE respondents asserted that it was more appropriate to describe that choice as a 'half-half' consideration when describing political concerns versus profits concerns.

Current mining internationalization is more like half 'administrative actions' and half 'commercial activities' for SOEs. As a SOE, we should be obliged to respond to the national call, but economic benefits are something we cannot avoid to consider either. (SOE, CEO)

Institutional influences have contributed to this balance between 'political considerations' and 'profits' in different ways. In the 1980's, during the first wave of Chinese firm internationalisation, political considerations dominated and were directly related to state interests. However, from the introduction of the 'go global policy', profitability considerations have had a more positive impact on each firm's internationalization decisions. Further, more recent alerts from State-owned Assets Supervision and Administration Commission (SASAC) and the State government indicate that more rigorous assessments and reviews of a firm's profitability and performance are being monitored (SASAC, 2012; Xinjiang Daily, 2012); the SOEs now weigh 'profits concerns' to a greater degree. 
Table 3 Comparison of The Key Criteria in Chinese Steel SOE and NSOE's OFDI

\begin{tabular}{|c|c|c|c|}
\hline \multicolumn{2}{|c|}{ Types of steel firm } & SOE & NSOE \\
\hline \multicolumn{2}{|c|}{$\begin{array}{c}\text { Motivations } \\
\text { (ranking from most to } \\
\text { least important) }\end{array}$} & $\begin{array}{ll}\text { 'Half-political \& Half-profits driven' } \\
\text { - } & \text { Resource-seeking; } \\
\text { - } & \text { Conformity to other SOEs; } \\
\text { - } & \text { Political obligation; } \\
\text { - } & \text { Information-seeking; } \\
\text { - } & \text { Strategic asset-seeking } \\
\text { - } & \text { Foreign market-seeking. }\end{array}$ & $\begin{array}{ll}\text { - } & \text { 'Profits driven' } \\
\text { - } & \text { Information-seeking; } \\
\text { - } & \text { Strategic asset-seeking; } \\
\text { - } & \text { Foreign market-seeking. }\end{array}$ \\
\hline Risk : & titudes & 'Risk tolerating' & 'Risk averse' \\
\hline \multicolumn{2}{|c|}{$\begin{array}{c}\text { First internationalization } \\
\text { experience }\end{array}$} & 1985-1986 & $2002-2003$ \\
\hline \multirow[t]{2}{*}{$\begin{array}{l}\text { Location } \\
\text { choices }\end{array}$} & $\begin{array}{l}\text { Resources/ } \\
\text { Mines }\end{array}$ & \begin{tabular}{ll}
\multicolumn{2}{l}{ Location of mines } \\
- & Peru \\
- & Australia \\
- & Brazil \\
- & Malaysia \\
- & Canada \\
Geological prospecting \\
- & Indonesia \\
- & The Philippines \\
- & Mongolia \\
- & Australia \\
- & Sudan \\
Trading houses \\
- $\quad$ Hong Kong \\
- $\quad$ Singapore
\end{tabular} & $\begin{array}{l}\text { Location of mines } \\
\text { - Australia } \\
\text { Geological prospecting } \\
\text { - N/A }\end{array}$ \\
\hline & $\begin{array}{l}\text { Export } \\
\text { markets }\end{array}$ & $\begin{array}{l}\text { - } \text { Algeria } \\
\text { - } \text { Middle east } \\
\text { - } \text { India } \\
\text { - Korea } \\
\text { - } \text { Thailand } \\
\text { - Russia } \\
\text { - USA } \\
\text { - Africa } \\
\text { - } \text { Europe }\end{array}$ & $\begin{array}{ll}\text { - } & \text { Hong Kong } \\
\text { - } & \text { Indonesia } \\
\text { - } & \text { Japan } \\
\text { - } & \text { Korea } \\
\text { - } & \text { Singapore } \\
\text { - } & \text { Thailand } \\
\text { - } & \text { UAE } \\
\text { - } & \text { USA } \\
\text { - } & \text { Vietnam }\end{array}$ \\
\hline
\end{tabular}

Resources-seeking is the primary motive for SOE internationalization, but demand is not unlimited as a motive. According to the Chairman of the SOE:

In the steel industry, China has been requiring iron ore because it's been boosting its GDP and domestic development. If this lasts for another 30 years, China would finally reach the point that scrap and scrap metal recycling can 
sufficiently meet its demand. European countries supply over $70 \%$ of their steel products through recycling. China will not [then] be continuously 'hungry' for the inputs of iron ore and coal like it is now...

In contrast, the initial motive for seeking resource inputs of NSOE is a lessinstitutionalized influenced decision. Home institutions have a limited impact on its internationalization decisions. The deputy CEO of the NSOE stated:

It was just a coincidence for us to undertake the first internationalization. But we soon realized how much benefits we could get through OFDI. Then, we have been operating the firm on a 'global market' scale. This naturally requires the acquisition of machineries, materials and resources in both local and foreign destinations. At the same time, we also export the finished steel products worldwide.

The Board member further added:

The Chinese government policies would have some impacts on us, as we are 'Chinese firms' after all; but those policies would not be strong enough to alter our internationalization strategies at this stage. The 'go global policy' provides a more flexible environment for us to undertake any overseas investment.

All respondents from the steel NSOE acknowledged that 'resources-seeking' is their key motive. However, the Head of the Australian Subsidiary pointed out that it is more accurate to term its motive as 'profit-driven'- meaning that the resources are just tools that enable the firm to be profitable. In his words:

We don't just acquire resources overseas; instead, we have always emphasized the rate of return on investment. We want to maximize the firm's profits through our international projects. Of course, at the same time, the projects often need to fulfil our requirements for resources.

In the literature on FDI, foreign market- seeking motives are considered the most important reason for firms to invest abroad (Brienen, et al., 2010). However, our findings reveal that this is not the case for steel firms in China. The head of the International Trading Department at the NSOE stated:

We have a good domestic market share. The pressure from domestic competition is a good thing for us, but it is not a strong motivation for international expansion.

In contrast, the market- seeking motive for the steel SOE is considered as more important. This firm's trading is very established in key regions, such as North America and Asia. The Head Administrative Officer explained: 
Unlike other NSOEs, our products are much more diversified. Instead of just having steel- related finished products, we have a multi-discipline group across multiple industries. It is, therefore, more important for us to look for new international markets...

Both firms in the case study have offices in Hong Kong and Singapore which they described as 'trading houses'. Yet their role and functions share both differences and commonalities. The CEO of the NSOE emphasised a strong international market trend driven by competitive pressures that resulted in the establishment of these trading houses, thus underpinning their international operations for finished steel products:

We had established Hong Kong and Singapore offices for our finished steel products. Now we are planning to set up America, Dubai, Korea, Europe, and South-East Asia offices in order to further enhance the sales and distribution channels within these regional markets.

The senior manager of SOE highlighted a broader range of trading activities in which the SOE have been involved:

We established subsidiaries in Hong Kong and Singapore. They have been performing the functions of international financing; overseas ore trading platforms; contact points for suppliers and ship owners; and promoting the finished steel products.

Both firms claimed these trading houses are the 'information centre' for the latest industrial news delivered in their own words. The CEO of the NSOE stated:

We need to spread to Hong Kong and Singapore to gather and analyse global industrial information. This information is critical for us to serve the investments and managerial decisions

These findings reveal that the SOE did have the same location choices as a rationale for establishing its 'trading houses'. However, their role is broader. They not only focus on international financing and their firms' finished products; they also provide a trading platform for mineral ores and a contact point for local suppliers and ship owners. 
The CFO of the NSOEs added:

These companies can be used as financial platforms - since they are both located in the world's financial centres-accessing the latest information and convenience of financing is the main motivation (for their establishment)

The CEO of the SOE offered this overview:

Hong Kong and Singapore are our 'window companies', which serve an important function. That is the information-seeking purpose and provides feedback from international mining markets.

This movement directly relates to the degree of freedom of information in mainland China and the opinion of the SOE respondents' suggesting that relevant (domestic) financial service advice is not as reliable or transparent as are the information sources in markets like Hong Kong or Singapore.

Further, seeking foreign markets provides an alternative way to earn foreign currencies, thereby allowing firms to 'self-fund' the steel NSOE overseas investments under the current exchange-controlled circumstance in China. Given the dominant market position that this NSOE has in China, it is not too difficult for it to obtain Chinese bank support. Yet, the firm has its own preference. In the words of the CEO of this NSOE:

We own sufficiently enough funds to make overseas investments in mines and resources. The profitability of exports in the overseas markets is planned to be generated as an independent venture investments fund. That's our future planning.

Such is not the case for the SOE. The respondents here discounted strategic-asset seeking as a motivation:

We own world-standard mining skills and smelting technology in our field; only specific managerial issues need to be looked at in terms of strategic-asset seeking.

The SOE respondents believed that only human capital-embodied in international business specialists and managerial skills - are worth acquiring through internationalization. However, no additional information was offered on how to access these strategic assets. In contrast, all of the interviewees from the NSOE admitted that the possibility of acquiring advanced technologies abroad is attractive, and they are keen to acquire various kinds of strategic assets, including the human capital that is found in international business specialists and managerial skills. 
The managers from the NSOE remarked on overcoming those weaknesses both in the short and the long term:

We emphasise improving our product quality, acquiring international brands, and also getting world standard product certifications in order to improve our management skills and production capabilities.

The CEO from the NSOE further added:

To solve the human resources problem, professional managers may not fit our corporate culture in the short term. They may find it difficult to adapt to and be integrated into the firm's environment. I therefore believe 3 to 5 years is required to recruit and train reserve personnel. And we should send large numbers of expatriates for training in our foreign businesses and select the best ones from there. It's so important for us to acquire managerial skills through internationalization, especially when we intend to manage our overseas employees from the developed countries. They don't have the identity of your cultural, management system, and management ability. And indeed, there are whole lots of better things to learn from them.

These findings show a certain consistency with those researchers (Deng, 2003, 2004; Dunning \& Lundan, 2008) who have highlighted that multiple motivations may indeed apply to Chinese firms.

Therefore, our first set of propositions are:

P1: Resource-seeking FDI is a motivation for both SOEs and NSOEs in the Chinese steel industry, but political strategic considerations reside in SOEs rather than with NSOEs

P2: Resource-seeking FDI is a motivation for both SOEs and NSOEs in the Chinese steel industry, but seeking scarce resources for the domestic market resides in NSOEs rather than with SOEs

P3: Foreign market seeking FDI is a motivation for both SOEs and NSOEs in the Chinese steel industry, as intensive domestic competition forces both SOEs and NSOEs to seek new markets abroad

P4: Strategic asset-seeking FDI is a motivation for both SOEs and NSOEs in the Chinese steel industry, but accessing strategic assets resides in NSOEs rather than with SOEs 


\section{Risk Attitudes and Location Choices}

Buckley, et al., (2007) found that Chinese outward direct investors had a paradoxical attitude toward risk, and risk aversion could not be assumed (UNCTAD, 2007). This claim was largely based on an analysis of Chinese SOEs. Our study shows that a SOE's paradoxical risk attitude is generated by three key issues. First is the separation of the ownership/manager role, which has the effect of weakening overall responsibility. Secondly, the leadership style of the appointee can be influential. Hong Kong Subsidiary CEO noted:

All of the strategic plans are based on a top leader's preferences to develop and adjust. At the end of each term, there will be a new leadership with a new strategy, so this is inevitable that we have to change along with the idea. For example, our former top leader was about to retire. He did not want to internationalise, nor make any big mistake prior to his retirement. Our attitude toward risk was 'aversion' or even 'escape'. It's very different since the new leader came. The risk attitude has logically been much more radical.

The third factor is overall capability, which is closely related to strong institutional support. The manager responsible for the international operations of the SOE stated:

We are SOEs. We can afford huge losses or failure; therefore, we can be more 'risk-tolerating'. We dare to invest in Africa or Central Asia because if anything (bad) happens, we will survive, but for a NSOE, it can be a fatal blow.

Respondents across the NSOE's explained that they adopted a 'risk averse' attitude toward international expansion, thus confirming the findings of Liu et al., (2005), which indicated that most Chinese NSOEs are risk averse rather than opportunity seeking. As the NSOE's CFO stressed:

We need to be especially good to control our investments and money. Unlike SOEs, if we had bad debts, we still have the responsibility to repay the bank, given it's done through a bank loan.

The SOE has more diversified locations than the NSOE - five countries (Peru, Australia, Brazil, Malaysia, and Canada) compared to one country (Australia). The SOE also has multiple locations for its geological prospecting (Indonesia, The Philippines, Mongolia, Australia, and Sudan) compared to none for the NSOE. According to the respondents, longer international experience and different firm resources and capabilities (highlighted in Table 3) contribute to this variation.

'Risk averse' ensures that geographically close developed countries (e.g. Australia) have been targeted by the NSOE. The respondents claimed that such a 
choice is associated with multiple benefits - political stability, transparency in governance, predictability for future expenditures, and geographically economical (in terms of shipping costs). Although the NSOE is not operating in 'low-cost' locations, it does indicate evidence of obtaining 'lower-cost resources'. The NSOE's head of overseas operations emphasised:

Since we are located in a perfect port along the coast, it's even cheaper to sea freight the minerals from Australia than from China. At the same time, the quality of the minerals is much higher. [Therefore] why don't we invest in Australia and use the resources as our own long-term, stable and low-costs inputs?

\section{The Vice Principal of NSOE stated:}

The greatest advantage of investing in the developed countries is that all costs are predictable. It's obviously a good way of managing the internationalization risks.

Therefore, our second set of propositions are:

This leads to our final two propositions:

P5: Significant institutional support from the Chinese government implies that China's steel SOEs are more 'risk tolerating' in their assessment of geographic market selection.

P6: Based on their longer international experience. Chinese steel SOEs invest in broader international locations while NSOEs prefer geographically close markets and developed countries.

\section{CONCLUSION}

We regard our contributions to the literature from this study as fourfold. First, multiple motivations apply to Chinese steel firm internationalization. Some, such as resources-seeking and strategic-asset seeking, are common for both the SOE and the NSOE. Other emerging motives, including information-seeking (embodied in the establishment of subsidiaries in both Hong Kong and Singapore), are also shared by both firms. 'Pressure', or conformity, to globalise and regionalise is unique to the SOE. However, the incentives of these motivations vary between the SOE ('half'political and 'half'profit- driven) and the NSOE (profit- driven) while seeking resources.

Second, institutional factors have a significant impact on internationalization motivations and risk attitudes of the steel SOE. Both home and host country's institutional factors determine both firm capacities and the implementation of firm strategies. These, in turn, shape their motivations and risk attitudes. 
Third, the location choices of both firms for their trading houses highlight the need of steel firms to access more transparent and comprehensive industry information and do so more efficiently. Those choices also provide opportunities to 'tap into' both of their lucrative financial markets.

Finally, institutional factors influence both the risk attitudes of both firms and their multinational experience and help determine their location choices. Although internationalisation for any mining firm is a relatively high risk action, it differs for the SOEs and the NSOEs due to the varying levels of institutional support from their home government. Based on 'higher' levels of institutional support, the SOE developed significant multinational experience and, consequently, enjoyed a greater capability to invest in broader geographic locations (i.e., Africa and Central Asia) while the NSOE gave its preference to more stable markets, both politically and economically so.

\section{MANAGERIAL IMPLICATIONS AND RESEARCH LIMITATIONS}

The findings of this study offer several managerial implications. First, the study reveals that motivations for OFDI from Chinese mining firms are determined by both economic and institutional factors. The institutional distinctiveness for the types of Chinese mining firms leads to two sets of multiple motivations for SOEs and NSOEs. Therefore, managers cannot view them in isolation. Such understanding will help managers develop key relevant strategies and generate effective negotiation skills to deal with Chinese mining SOEs and NSOEs.

Second, the findings on the intangible assets of institutional factors that Chinese mining SOE own allow this state-owned enterprise to undertake large-scale projects in risky markets. This finding suggests that if there is an intention to attract Chinese mining investors, SOEs tend to act in more 'risk-tolerating' ways than do NSOEs.

Further, the SOE is less concerned about distance and cost issues associated with geographic locations. The managers from Chinese mining associations should review the various risk attitudes and provide independent risk evaluation supports to assist those firms who intend to invest in overseas projects, in order to provide a second opinion separate from the firm's own risk evaluation to check for any possible bias.

Several limitations of this study also need to be noted. The current research accessed just two case studies. The next step is to conduct more case studies from both Chinese mining SOEs and NSOEs beyond the steel sector with the goal of further exploring the key issues offered here and generalize them to other sectors of the Chinese mining industry. Furthermore, the scale of the firms selected in the current study was large. Their relevant behaviour may be not representative, as SOEs 
and NSOEs from other scale categories (e.g. small to medium size) were not included in this effort.

\section{REFERENCES}

Agarwal, S. \& Ramaswami, S. N. (1992). Choice of Foreign Market Entry Mode: Impact of Ownership, Location and Internalization Factors. Journal of $\begin{array}{llll}\text { International } \quad \text { Business } & \text { Studies, } & \text { 23(1): }\end{array}$ http://dx.doi.org/10.1057/palgrave.jibs.8490257

Ahlstrom, D. \& Bruton, G. D. (2008). Private firms in China: Building legitimacy in an emerging economy. Journal of world business, 43(4), 385-99. http://dx.doi.org/10.1016/j.jwb.2008.03.001

Alden, C. \& Davies, M. (2006). A Profile of the Operations of Chinese Multinationals in Africa. South African Journal of International Affairs, 13(1), 83-96. http://dx.doi.org/10.1080/10220460609556787

Alon, I., Chang, J., Fetscherin, M., Lattemann, C., \& Mclntyre, J. R. (2009). China Rules: Globalizatin and Political Transformation. Hampshire UK: Palgrave Macmillan.

Askci. (2012). Chinese NSOE accounted nearly 44\% of total OFDI flow in 2011. http://www.askci.com/news/201203/16/161332_06.shtml.

Ayyub, B. M., Prassinos, P. G., \& Etherton, J. (2010). Risk Informed Decision Making. Mechanical Engineering, 132(1), 28-33.

Bausch, A. \& Krist, M. (2007). The effect of context-related moderators on the internationalization-performance relationship: evidence from meta-analysis. (Report). Management International Review, 47(3), 319(29). http://dx.doi.org/10.1007/s11575-007-0019-z

Beer, T. \& Ziolkowski, F. (1995). Environmental risk assessment: An Australian perspective. Barton ACT Australia: Commonwealth of Australia.

Behrman, J. N. (1969). Some Patterns in the Rise of the Multinational Enterprise. NC: University of North Carolina: Chapel-Hill.

Brienen, M. J., Burger, M. J., \& Oort, F. G. V. (2010). The Geography of Chinese and Indian Greenfield Investments in Europe. Eurasian geography and economics, 51(2), 254-73. http://dx.doi.org/10.2747/1539-7216.51.2.254 
Brouthers, K. D. \& Brouthers, L. E. (2000). Acquisition or Greenfield Start-up? Institutional, Cultural and Transaction Cost Influences. Strategic Management Journal, 21(1), 89-97. http://dx.doi.org/10.1002/(SICI)10970266(200001)21:1\%3C89::AID-SMJ85\%3E3.3.CO;2-\%23

Brouthers, K. D., Brouthers, L. E., \& Werner, S. (1996). Dunning's eclectic theory and the smaller firm: The impact of ownership and locational advantages on the choice of entry-modes in the computer software industry. International Business Review, 5(4), 377-94. http://dx.doi.org/10.1016/0969-5931(96)00019-4

Buckley, P. J. (2008). Do we need a special theory of foreign direct investment for extractive industries? Journal of Chinese Economic and Foreign Trade Studies, 1(2), 93-104. http://dx.doi.org/10.1108/17544400810884682

Buckley, P. J. \& Casson, M. (1976). The Future of the Multinational Enterprise. London: Macmillan.

Buckley, P. J., Clegg, L. J., Cross, A. R., Xin, L., Voss, H., \& Ping, Z. (2007). The determinants of Chinese outward foreign direct investment. Journal of International Business Studies, 38(4), 499-518. http://dx.doi.org/10.1057/palgrave.jibs. 8400277

Cai, K. G. (1999). Outward Foreign Direct Investment: A Novel Dimension of China's Integration into the Regional and Global Economy. The China Quarterly(160): 856-80. http://dx.doi.org/10.1017/S0305741000001363

CCC. (2013). Mining Capital: How Canada has transformed its resource endowment into a Global competitive advantage. Ottawa, Toronto, Montreal, Galgary: The Canadian Chamber of Commerce.

Chuan, C. \& Orr, R. J. (2009). Chinese Contractors in Africa: Home Government Support, Coordination Mechanisms, and Market Entry Strategies. Journal of Construction Engineering \& Management, 135(11), 1201-10. http://dx.doi.org/10.1061/(ASCE)CO.1943-7862.0000082

Contractor, F. J. \& Lorange, P. (1988). Cooperative Strategies in International Business: Joint Venture and Technology Partnerships between Firms. 1st edition ed. Oxford: D.C. Heath and Company.

Corkin, L. (2007). The Strategic entry of China's Emerging Multinationals into Africa. China Report, 43(3), 309-22. http://dx.doi.org/10.1177/000944550704300303

Davies, M., Edinger, H., Tay, N., \& Naidu, S. (2008). How China delivers development assistance to Africa. Stellenbosch, South Africa: Centre of Chinese Studies, University of Stellenbosch.

Deng, P. (2003). Foreign Investment by Multinationals from Emerging Countries: The Case of China. Journal of Leadership \& Organizational Studies, 10(2), 113-24. 
Deng, P. (2004). Outward investment by Chinese MNCs: Motivations and implications. Business Horizons, 47(3), 8-16. http://dx.doi.org/10.1016/S00076813(04)00023-0

Deng, P. (2007). Investing for strategic resources and its rationale: The case of outward FDI from Chinese companies. Business Horizons, 50(1), 71-81. http://dx.doi.org/10.1016/j.bushor.2006.07.001

Dubois, A. \& Gadde, L.-E. (2002). Systematic combing: an abductive approach to case research. Journal of Business Research, 55(7), 553-60.

Dunning, J. (1977). Trade, Location of Economic Activity and the MNE: A Search for an Eclectic Approach. In Hesselborn, P.O. \& P.M.Wijkmon, (Eds.), The International Location of Economic Activity. London: Macmillan.

Dunning, J. (1998). Location and the multinational enterprise: A neglected factor? Journal of International Business Studies, 29(1), 45-66. http://dx.doi.org/10.1057/palgrave.jibs.8490024

Dunning, J. (2000). The eclectic paradigm as an envelope for economic and business theories of MNE activity. International Business Review, 9, 163-90. http://dx.doi.org/10.1016/S0969-5931(99)00035-9

Dunning, J. (2001). The Eclectic (OLI) Paradigm of International Production: Past, Present and Future. International Journal of the Economics of Business, 8(2), 173 - 90. http://dx.doi.org/10.1080/13571510110051441

Dunning, J. (2009). Location and the multinational enterprise: A neglected factor? Journal of International Business Studies, 40(1), 5-19. http://dx.doi.org/10.1057/jibs.2008.74

Dunning, J. \& Lundan, S. M. (2008). Multinational enterprises and the global economy (2nd ed.). Edward Elgar Publishing Limited.

Dunning, J. H. (1993). Multinational Enterprises and the Global Economy. Suffolk: Addison-Wesley Publishing Company.

Eisenhardt, K. M. (1989). Building Theories from Case Study Research. The Academy of Management Review, 14(4), 532-50. http://dx.doi.org/10.5465/AMR.1989.4308385

Ericsson, M. (2010). African countries prepare for the continued mining boom. Mining in Africa: 9-10.

First Finance Daily. (2010). Conform to the trend of rising labor costs.

Fletcher, M. \& Plakoyiannaki, E. (2011). Case selection in international business: key issues and common misconceptions.In Piekkari, Rebecca \& Catherine Welch, (Eds.). Rethinking the case study in international business and management research. Cheltenham, UK, Northampton, MA, USA: Edward Elgar. 
Flick, U. (2008). Managing Quality in Qualitative Research. Thousand Oaks, CA: Sage Publications.

Gao, L., Liu, X., Zou, H., \& Tu, L. (2010). How do dynamic capabilities and institutions influence the post internationalisation performance of Chinese stateowned Firms? Paper presented at CEA UK/Europe 2010 annual conference, Oxford.

Ghauri, P. 2004. Designing and Conducting Case Studies in International Business Research.In Marschan-Piekkari, Rebecca \& Catherine Welch, (Eds.), Handbook of Qualitative Research Methods for International Business. Cheltenham, UK; Northampton, MA, USA: Edward Elgar Publishing.

$\mathrm{Gu}$, J. (2009). China's Private enterprises in Africa and the Implications for African Development. European journal of development research, 21(4), 570-606. http://dx.doi.org/10.1057/ejdr.2009.21

Guion, L. A., Diehl, D. C., \& McDonald, D. (2011). Triangulation: Establishing the validity of qualitative studies. Department of Family, YCS, University of Florida.

Haglund, D. (2008). Regulating FDI in weak African states: a case study of Chinese copper mining in Zambia. Journal of Modern African Studies, 46(4), 547-75. http://dx.doi.org/10.1017/S0022278X08003480

He, W. \& Lyles, M. A. (2008). China's outward foreign direct investment. Business Horizons, 51(6), 485-91. http://dx.doi.org/10.1016/j.bushor.2008.06.006

Holloway, J., Roberts, I., \& Rush, A. (2010). China's Steel Industry, RBA Bulletin. Sydney: Reserve Bank of Australia.

Huang, M. F. (2008). A Surney on the Situation of Going Global of Non-State-Owned Enterprises in China. Beijing, China: China Financial \& Economic Publishing House.

Jiang, Y. (2009). China's status quo and thoughts about outward mining investments since 2008. http://www.china5e.com.

Kang, Y. \& Jiang, F. (2012). FDI location choice of Chinese multinationals in East and Southeast Asia: Traditional economic factors and institutional perspective. Journal of World Business, 47(1), 45-53. http://dx.doi.org/10.1016/j.jwb.2010.10.019

Kim, W. C. \& Hwang, P. (1992). Global Strategy and Multinationals' Entry Mode Choice. Journal of International Business Studies, 23(1), 29-53. http://dx.doi.org/10.1057/palgrave.jibs.8490258

Kolstad, I. \& Wiig, A. (2012). What determines Chinese outward FDI? Journal of World Business, 47(1): 26-34. http://dx.doi.org/10.1016/j.jwb.2010.10.017 
KPMG \& SCSC. (2012). Demystifying Chinese Investment: China outbound direct investment in Australia Sydney. Sydney China Study Center,.

Kraemer, R. \& Tulder, R. v. (2009). Internationalization of TNCs from the extractive industries: a literature review. Transnational Corporations, 18(1), 137-56.

Kumar, N. \& Chadha, A. (2009). India's outward foreign direct investments in steel industry in a Chinese comparative perspective. Industrial and corporate change 18(2), 249-67. http://dx.doi.org/10.1093/icc/dtp004

Liu, S. (2011). True level of development. http://www.chinadaily.com.cn/cndy/201106/07/content_12646256.htm.

Liu, X., Buck, T., \& Shu, C. (2005). Chinese economic development, the next stage: outward FDI? International Business Review, 14(1), 97-115. http://dx.doi.org/10.1016/j.ibusrev.2004.12.003

Lu, T. (2003). Transnational business strategy of Chinese enterprises. Beijing: Economic Management Press.

Luo, Y. \& Peng, M. W. (1999). Learning to Compete in a Transition Economy: Experience, Environment, and Performance. Journal of International Business Studies, 30(2), 269-95. http://dx.doi.org/10.1057/palgrave.jibs.8490070

Luo, Y., Xue, Q., \& Han, B. (2010). How emerging market governments promote outward FDI: Experience from China. Journal of World Business, 45(1), 68-79. http://dx.doi.org/10.1016/j.jwb.2009.04.003

M2PressWire. (2009). China Mining Report Q2 2009. M2Press WIRE.

Madhok, A. (1997). Cost, value and foreign market entry mode: the transaction and the firm. Strategic Management Journal, 18(1), 39-61. http://dx.doi.org/10.1002/(SICI)1097-0266(199701)18:1\%3C39::AIDSMJ841\%3E3.3.CO;2-A

Miles, M. \& Huberman, A. (1994). Quantitative data analysis: An expanded sourcebook. Newbury Park: Sage Publications.

MOFCOM, SAFE, \& NBS. (2006. 2005) Statistical bulletin of China's outward foreign direct investment. Beijing, China: Ministry of Commerce.

MOFCOM, SAFE, \& NBS. (2007. 2006) Statistical bulletin of China's outward foreign direct investment. Beijing, China: Ministry of Commerce.

MOFCOM, SAFE, \& NBS. (2008. 2007) Statistical bulletin of China's outward foreign direct investment. Beijing, China: Ministry of Commerce.

MOFCOM, SAFE, \& NBS. (2009. 2008) Statistical bulletin of China's outward foreign direct investment. Beijing, China: Ministry of Commerce.

MOFCOM, SAFE, \& NBS. (2010. 2009) Statistical bulletin of China's outward foreign direct investment. 15-11-2010 ed. Beijing, China: Ministry of Commerce. 
MOFCOM, SAFE, \& NBS. (2011. 2010) Statistical bulletin of China's outward foreign direct investment. 16-09-2011 ed. Beijing, China: Ministry of Commerce. MOFCOM, SAFE, \& NBS. (2012. 2011) Statistical bulletin of China's outward foreign direct investment. August 2012 ed. Beijing, China: China Statistics Press.

Morck, R., Yeung, B., \& Zhao, M. (2008). Perspectives on China's outward foreign direct investment. Journal of International Business Studies, 39(3), 337-50. http://dx.doi.org/10.1057/palgrave.jibs. 8400366

Nachum, L. (2000). Economic Geography and the Location of TNCs: Financial and Professional Service FDI to the USA. Journal of International Business Studies, 31(3), 367. http://dx.doi.org/10.1057/palgrave.jibs. 8490912

Naidu, S. \& Davies, M. (2006). China fuels its future with Africa's riches. South African Journal of International Affairs, 13(2), 69-83. http://dx.doi.org/10.1080/10220460609556803

Naidu, S. \& Mbazima, D. (2008). China-African relations: A new impulse in a changing continental landscape. Futures, 40(8), 748-61. http://dx.doi.org/10.1016/j.futures.2008.02.007

NBD China. (2009). 43\% of the Chinese mineral M\&As are in Australia. http://finance.sina.com.cn/money/nmetal/20091021/10393086290.shtml.

Nolan, P. \& Yeung, G. (2001). Large Firms and Catch-up in a Transitional Economy: The Case of Shougang Group in China. Journal Economics of Planning 34(2-2), 159-78.

Pak, Y. S. \& Park, Y.-R. (2005). Characteristics of Japanese FDI in the East and the West: Understanding the strategic motives of Japanese investment. Journal of World Business, 40(3), 254-66. http://dx.doi.org/10.1016/j.jwb.2005.05.003

Patton, M. (2002). Qualitative Research and Evaluation Methods. London: Sage Publications.

Peng, M. W., Sunny Li, S., Pinkham, B., \& Hao, C. (2009). The Institution-Based View as a Third Leg for a Strategy Tripod. Academy of Management Perspectives, 23(3), 63-81.

Peng, M. W., Wang, D. Y. L., \& Jiang, Y. (2008). An institution-based view of international business strategy: a focus on emerging economies. Journal of International Business $\quad$ Studies, 39(5), 920-36. http://dx.doi.org/10.1057/palgrave.jibs. 8400377

Porter, M. E. (1998). Clusters and the new economics of competition. Harvard Business Review: 77-90.

Qing, W. L. (2010). Rising labor costs, the manufacturing industries is imperative. http://info.ch.gongchang.com/a/main/2010-11-20/81554.html. 
Ramasamy, B., Yeung, M., \& Laforet, S. (2012). China's outward foreign direct investment: Location choice and firm ownership. Journal of World Business, 47, 17-25. http://dx.doi.org/10.1016/j.jwb.2010.10.016

Reuters. (2010). Australia and Canada is still the most favourable destination for overseas investments to Chinese mining companies. http://www.metalchina.com/members/news.php?id=422301.

Rockett, J. P. (1999). Definitions are not what they seem: Perpetuity Press.

Root, F. R. (1994). Entry Strategies for international markets. New York: Lexington Books.

Rosen, D. H. \& Hanemann, T. (2009). China's Changing Outbound Foreign Direct Investment Profile: Drivers and Policy Implicaitons. Peterson Institute for International Economics, Number PB09(14). http://ww.w.iie.com/publications/pb/pb09-14.pdf

SASAC. (2012). SASAC published 'central enterprises' overseas investment Interim Measures for the supervision and management'. 27 June 2012 ed.: SASAC.

Scott, W. R. (2002). The Changing World of Chinese Enterprise: An Institutional Perspective.In Tsui, Anne S \& Chung-Mining Lau, (Eds.), The Management of Enterprises in the People's Republic of China. Boston: Kluwer Academic Press.

Shen, X. (2013). How the private sector is changing Chinese investments in Africa. 15 April 2013 ed.: Columbia FDI Perspectives.

Sun, T. (2007). Canada: an international stage for mining investment. Shanxi Youth, 2007(1).

Taylor, R. (2002). Globalization strategies of Chinese companies: current developments and future prospects. Asian Business and Management, 1(2), 20925. http://dx.doi.org/10.1057/palgrave.abm.9200011

Tull, D. M. (2006). China's engagement in Africa: scope, significance and consequences. Journal of Modern African Studies, 44(3), 459-79.

UNCTAD. (2007). World Investment Report (2007). New York and Geneva: United Nations.

Voss, H., Buckley, P., \& Cross, A. R. (2008). Thirty Years of Chinese Outward Foreign Direct Investment. Paper presented at 19th CEA (UK) Conference: China's Three Decades of Economic Reform (1978-2008), University of Cambridge, UK.

Wang, J. \& Jiang, C. (2007). Global allocation of mineral resources. Beijing: Consulting \& Research Center Ministry of Land \& Resources, China.

Wang, X. (2009). Analysis of special factors for the internationalisation of mining company. China Mining Magazine, 16(5). 
World Steel Association. (2012). World Steel in Figures 2012. http://www.worldsteel.org/media-centre/press-releases/2012/wsif.html.

Wright, M., Filatotchev, I., Hoskisson, R. E., \& Peng, M. W. (2005). Strategy Research in Emerging Economies: Challenging the Conventional Wisdom. Journal of Management Studies, 42(1), 1-33. http://dx.doi.org/10.1111/j.14676486.2005.00487.x

Xinjiang Daily. (2012). SASAC's accountability to SOEs' losses. http://roll.sohu.com/20110806/n315630714.shtml.

Yin, R. (2009). Case Study Research. 4th ed. Beverly Hills, CA: Sage Publications.

Zafar, A. (2007). The Growing Relationship Between China and Sub-Saharan Africa: Macroeconomic, Trade, Investment, and Aid Links. The World Bank Research Observer 22(1), 103-30. http://dx.doi.org/10.1093/wbro/lkm001 
